\title{
Phenotypic correlations of fatty acid composition among intramuscular, subcutaneous and intermuscular fat tissues in concentrate-fed beef cattle of differing genotypes
}

\author{
N. Aldai ${ }^{1}$, M. E. R. Dugan ${ }^{1}$, K. Osoro ${ }^{2}$, Z. Wang ${ }^{3}$, D. H. Crews, Jr. ${ }^{3,4}$, and C. $\mathrm{Li}^{1,3}$ \\ ${ }^{1}$ Agriculture and Agri-Food Canada, Lacombe Research Centre, 6000 C\&E Trail, Lacombe, Alberta, Canada T4L \\ 1W1 (e-mail: naldai001@ikaste.ehu.es; changxi.Li@agr.gc.ca); ${ }^{2}$ Área de Sistemas de Producción Animal, Servicio \\ Regional de Investigación y Desarrollo Agroalimentario, Apdo. 13, 33300 Villaviciosa, Asturias, Spain; ${ }^{3}$ Department \\ of Agricultural, Food and Nutritional Science, University of Alberta, Edmonton, Alberta, Canada T6G 2P5; and \\ ${ }^{4}$ Department of Animal Sciences, Colorado State University, Fort Collins, Colorado 80523, USA. \\ Received 5 September 2008, accepted 11 December 2008.
}

\begin{abstract}
Aldai, N., Dugan, M. E. R., Osoro, K., Wang, Z., Crews, D. H., Jr. and Li, C. 2009. Phenotypic correlations of fatty acid composition among intramuscular, subcutaneous and intermuscular fat tissues in concentrate-fed beef cattle of differing genotypes. Can. J. Anim. Sci. 89: 67-70. In an attempt to predict intramuscular fatty acid composition using easily accessible fat depots, between-tissue correlations were studied in 75 Asturiana de los Valles bulls with different levels of muscular hypertrophy, and 25 Asturiana de la Montaña bulls. Trans-18:1 in intramuscular fat was highly and positively correlated with levels in subcutaneous and intermuscular fats, while levels of total n-3 were not correlated. Predicting intramuscular fatty acid composition using easily accessible depots is thus possible for some fatty acids exhibiting high between-tissue correlations (e.g., trans-18:1) but breed and tissue specific deposition may limit this for others (e.g., n-3 fatty acids).
\end{abstract}

Key words: Beef, fat tissue, fatty acid, correlation

\begin{abstract}
Aldai, N., Dugan, M. E. R., Osoro, K., Wang, Z., Crews, D. H., Jr. et Li, C. 2009. Corrélations phénotypiques de la composition en acides gras des tissus adipeux intramusculaires, sous-cutanés et intermusculaires chez divers génotypes de bovins engraissés avec des concentrés. Can. J. Anim. Sci. 89: 67-70. Dans l'espoir de prédire la composition en acides gras de la graisse intramusculaire à partir des dépôts de gras aisément accessibles, les auteurs ont examiné les corrélations tissulaires chez 75 taureaux Asturiana de los Valles présentant un degré variable d'hypertrophie musculaire et chez 25 taureaux Asturiana de la Montaña. La concentration d'acides gras trans-18:1 dans la graisse intramusculaire est fortement et positivement corrélée à celle observée dans le gras sous-cutané et intermusculaire, alors qu'il n'existe aucune corrélation pour la concentration totale d'acides gras n-3. Il est donc possible de prévoir la composition en acides gras de la graisse intramusculaire à partir des dépôts de gras facilement accessibles pour les acides gras présentant une grande corrélation dans les différents tissus (à savoir, acides gras trans-18:1), mais la race et des dépôts spécifiques à certains tissus pourraient restreindre de telles prévisions pour les autres types d'acides gras (par ex., acides gras n-3).
\end{abstract}

Mots clés: Bœuf, tissu adipeux, acides gras, corrélation

The composition and level of fat in beef are economically relevant traits because of their association with eating quality and consumer acceptability (Webb and O'Neill 2008), and their human health implications (Ulbricht and Southgate 1991). The relationship between trans fat consumption and cardiovascular disease has recently prompted new recommendations for food labelling in Canada (Health Canada 2006). On the other hand, possible health benefits have been identified for some fatty acids including conjugated linoleic acids (CLA), specifically rumenic acid (cis9,trans 11-18:2), and its precursor vaccenic acid (trans11-18:1) present in ruminant fats (Belury 2002). Opportunities, therefore, exist to develop beef products with enhanced or optimized fatty acid profiles, which will increase consumer satisfaction due to perceived human health benefits.

Changing the fatty acid composition of beef has typically been done by dietary means, but deposition

Abbreviations: AM, Asturiana de la Montaña; AV, Asturiana de los Valles; CLA, conjugated linoleic acids; FAME, fatty acid methyl esters; GC, gas chromatography; IM, intramuscular; IT, intermuscular; SC, subcutaneous 
of fatty acids in beef tissues is under complex control and depends on the pathways and rates of ruminal polyunsaturated fatty acid biohydrogenation and genetic factors governing the deposition and turnover rates of individual fatty acids (Kramer et al. 2004; Scollan et al. 2006). Genetic factors governing the deposition and turnover rates of individual fatty acids are not well understood, but breed has been found to influence beef fatty acid composition (Choi et al. 2000; Aldai et al. 2007). In this sense, phenotypic correlations of fatty acids among various beef tissues could provide a means for predicting selected fatty acid contents in tissues not readily accessible (e.g., muscle) using the measures from easily accessible tissues (e.g., subcutaneous fat). The ability to use easily accessible tissues for prediction of muscle fatty acid compositions would, therefore, be useful in the design of genetic evaluation programs, but would also provide a quality control measure for the production of beef with consistent fatty acid profiles.

Basarab et al. (2007) recently reported relationships for cis9,trans11-18:2, total trans-18:1 and 18:3n-3 among tissues of longissimus thoracis, gastrocnemius, intercostal muscles, and subcutaneous and intermuscular fat depots in crossbred yearling steers. The steers were fed different diets designed to enrich tissue levels of these fatty acids and high and positive between-tissue correlations were found for the fatty acids reported. The present study investigated whether similar relationships would be found among concentrate-fed yearling bulls of Northern Spanish breeds: Asturiana de los Valles (AV), which is characterized by different levels of muscular hypertrophy, and Asturiana de la Montaña (AM).

All animals used in this study were cared for under the guidelines established by the European Union and they were slaughtered in a commercial abattoir according to standard procedures (Real Decreto 147/1993; OJEC 1999). One hundred yearling bulls were used in this study, including $25 \mathrm{AM}$, which are characterised as being small to medium-sized animals, and $75 \mathrm{AV}$. The AV animals included double-muscled $(m h / m h, n=24)$, heterozygotes $(m h /+, n=26)$ and normal homozygotes $(+/+, n=25)$ depending on the status of muscular hypertrophy determined by genotyping the 11-bp deletion in the coding sequence of the myostatin gene (Grobet et al. 1998). Aldai et al. (2007) previously described animal management in the feedlot, slaughtering procedures and tissue fatty acid analyses. Briefly, similar numbers of bulls per genotype were produced per year over a 3-yr period and these were finished on a high concentrate diet ( $84 \%$ barley, $10 \%$ soybean meal, $3 \%$ soybean oil, $3 \%$ minerals, vitamins and oligoelements). After slaughter ( $24 \mathrm{~h}$ post-mortem) meat (longissimus thoracis) and adipose tissue (subcutaneous and intermuscular fat) were dissected from the 8th rib region, vacuum packaged and frozen at $-80^{\circ} \mathrm{C}$ for subsequent fatty acid analysis. Prior to fatty acid analysis, tissues were thawed and ground through a 3- mm plate and then $1 \mathrm{~g}$ muscle or $30 \mathrm{mg}$ adipose tissue (subcutaneous and intermuscular) were saponified in $\mathrm{KOH}$ in methanol/water (50:50, vol/vol), fatty acids were methylated using trimethylsilyl-diazomethane in methanol/toluene $(2: 1, \mathrm{vol} / \mathrm{vol})$, and fatty acid methyl esters (FAME) were analyzed by GC using a CP Sil-88 $100 \mathrm{~m}$ column equipped with a FID detector (Aldai et al. 2006). Fatty acid contents were expressed as a percentage of total FAME. Individual and groups of fatty acids analyzed in this study included total trans-18:1, cis 9 , trans 11-18:2 (rumenic acid, coeluted with trans7,cis9-18:2), 18:2n-6 (linoleic acid), total n-6 (omega-6), 18:3n-3 (linolenic acid) and total n-3 (omega-3).

The partial Pearson phenotypic correlations of fatty acids among the intramuscular, subcutaneous and intermuscular fat tissues were obtained across all breeds using the CORR procedure of SAS (SAS Institute, Inc. 2001) following adjustment for identifiable fixed effects of year of birth, breed and $m h$ genotype. To further examine the impact of genotype or biological type on the relationship of fatty acids among the three different tissues, the partial Pearson phenotypic correlations were also calculated separately for each of the four genotypes (AV $m h / m h, \mathrm{AV} m h /+$, AV $+/+$, AM). Two-sided difference tests were performed to compare the $r$ coefficients between the different genotypes.

In general, the fatty acid composition of intermuscular and subcutaneous fat was strongly and positively correlated for all fatty acids examined $(r=0.71$ to 0.85 , $P<0.001$; Table 1). Fatty acids were also found to be significantly and positively correlated between the intramuscular and subcutaneous fat tissues $(r=0.39$ to $0.81, P<0.001)$ except for $18: 3 n-3(r=-0.01, P>0.05)$ and total n-3 fatty acids $(\mathrm{r}=-0.04, P>0.05)$, and between the intramuscular and intermuscular fat tissues $(r=0.42$ to $0.71, P<0.001)$ except for $18: 3 \mathrm{n}-3(r=-$ $0.03, P>0.05)$ and total $\mathrm{n}-3$ fatty acids $(r=0.00, P>$ $0.05)$. The low correlations of $18: 3 n-3$ between the intramuscular and subcutaneous as well as intermuscular fat tissue is in contrast to what Basarab et al. (2007) observed, in which a correlation of greater than 0.90 was reported among intramuscular, subcutaneous, and intermuscular fat tissues. The present results were based on feeding of a single high concentrate diet, whereas the

\begin{tabular}{|c|c|c|c|}
\hline Fatty acid (\%) & IM-SC & IM-IT & SC-IT \\
\hline trans-18:1 & $0.81 * * *$ & $0.71 * * *$ & $0.81 * * *$ \\
\hline cis 9, trans $11-18: 2^{\mathrm{Z}}$ & $0.70 * * *$ & $0.47 * * *$ & $0.71 * * *$ \\
\hline $18: 2 n-6$ & $0.44 * * *$ & $0.46^{* * *}$ & $0.85^{* * *}$ \\
\hline$n-6$ & $0.39 * * *$ & $0.42 * * *$ & $0.85^{* * *}$ \\
\hline $18: 3 n-3$ & $-0.01 \mathrm{NS}$ & $-0.03 \mathrm{NS}$ & $0.75^{* * *}$ \\
\hline$n-3$ & $-0.04 \mathrm{NS}$ & $0.00 \mathrm{NS}$ & $0.74 * * *$ \\
\hline
\end{tabular}

${ }^{\mathrm{z}}$ Coeluted with trans 7 , cis 9 -18:2.

$* * * P<0.001$; NS, $P>0.05$. 
results of Basarab et al. (2007) were based on feeding a number of diets differing widely in the fatty acid content and composition. Thus, high between-tissue correlations appear to be possible when there are great differences in the polyunsaturated fatty acid content of diets, but when a single diet is fed the relationship is lost.

In general, when correlations of fatty acids between fat tissues were calculated for each genotype (Table 2), correlations were consistent with those obtained across genotypes, but some inconsistencies were noted, which would be indicative of breed by tissue interactions. Interestingly, the correlations between tissues for total trans-18:1 were always positive and high for all four genotypes $(r=0.60$ to $0.97, P<0.001)$. The correlations of cis9,trans11-18:2 were also found to be positive and high between tissues for all AV genotypes $(r=0.43$ to $0.90, P<0.05$ ). In AM bulls, however, cis 9 , trans 11-18:2 was not correlated between the intramuscular and either subcutaneous $(r=0.29, P>0.05)$ or intermuscular fat $(r=-0.15, P>0.05)$, which may indicate a lack of relationship between adipose tissue and muscle $\Delta^{9}$ desaturase activity for this genotype. The high and positive correlations of trans-18:1 and cis9,trans11-18:2 are indicative of related rates of deposition of these fatty acids in triacylglycerol and phospholipids, irrespective of the tissue for $\mathrm{AV} m h / m h, \mathrm{AV} m h /+$ and $\mathrm{AV}+/+$ genotypes. High and positive correlations of trans-18:1 and cis9,trans11-18:2 were also found among the intramuscular, subcutaneous and intermuscular fat tissues of crossbred steers from different feeding systems by Basarab et al. (2007). Consequently, the use of easily accessible fat tissues (e.g., subcutaneous fat) to predict the level of trans-18:1 appears to be feasible irrespective of genotype, but predictions of cis9,trans11-18:2 in muscle are genotype/breed dependant.

The content of 18:2n-6 and 18:3n-3 also showed high and positive correlations between subcutaneous and intermuscular fats in all genotypes (Table $2 ; r=0.51$ to $0.96, P<0.01$ for $18: 2 \mathrm{n}-6 ; r=0.43$ to $0.91, P<0.05$ for $18: 3 n-3)$. In addition, consistent with data pooled across genotype, the correlations of $18: 3 n-3$ and total n-3 fatty acids between the intramuscular and either subcuta- neous or intermuscular fat were low and not significant except for 18:3n-3 in the AV $+/+$ and AM genotypes $(r=0.52, P<0.01$ in $\mathrm{AV}+/+$ and $r=0.53, P<0.01$ in AM for subcutaneous; $r=0.63, P<0.001$ in $\mathrm{AV}+/+$ for intermuscular). Subcutaneous and intermuscular adipose tissues are primarily composed of triacylglycerol and the high and positive correlations for all studied fatty acids between these depots confirms the relative similarity of their fatty acid composition. The variable correlation of $18: 3 n-3$ between the intramuscular and either subcutaneous or intermuscular adipose tissues in the genotypes studied likely relates to the high triacylglycerol content of subcutaneous and intermuscular tissues and the increasing triacylglycerol to phospholipid ratio when intramuscular fat level increases (De Smet et al. 2004). When the intramuscular fat content is low, as in the case of $\mathrm{AV} \mathrm{mh} / \mathrm{mh}$, the fatty acid composition of the muscle is reflective of membrane phospholipids where $18: 2 n-6$ is preferentially deposited. But when the neutral lipid concentration (triacylglycerols) increases, as in the case of $\mathrm{AV}+/+$, the fatty acid composition of the muscle fat begins to reflect the composition of the neutral lipids which deposit 18:3n-3 in equal proportions relative to polar lipids (phospholipids) (De Smet et al. 2004). Consequently, the muscle fatty acid composition begins to reflect the composition of triacylglycerol-rich subcutaneous and intermuscular fats. The AM bulls had more intramuscular fat $(2.39 \%)$ than any of AV bulls regardless of their genotype $(0.81 \%$ for $\mathrm{mh} / \mathrm{mh}, 1.77 \%$ for $m h /+, 1.85 \%$ for $+/+$; Aldai et al. 2007) and their 18:3n-3 levels in intramuscular fat were significantly correlated with levels in their subcutaneous fat $(r=0.53$ : $P<0.01)$, but not with levels in intermuscular fat $(r=$ $0.39, P>0.05)$. The accuracy of predicting the $18: 3 \mathrm{n}-3$ content of intramuscular fat using an easily accessible tissue will, therefore, depend on the type of tissue used for the prediction and the effects and interactions of diet, level of fatness and breed specific lipid metabolism.

The level of 18:3n-3 combined with its various elongation and desaturation products make up the total n-3 fatty acids. Interestingly, however, total n-3 in intramuscular fat was not correlated to levels in

\begin{tabular}{|c|c|c|c|c|c|c|c|c|c|c|c|c|}
\hline \multirow[b]{2}{*}{ Fatty acid $(\%)$} & \multicolumn{4}{|c|}{ IM-SC } & \multicolumn{4}{|c|}{ IM-IT } & \multicolumn{4}{|c|}{ SC-IT } \\
\hline & $m h / m h$ & $m h /+$ & $+/+$ & $\mathrm{AM}$ & $m h / m h$ & $m h /+$ & $+/+$ & $\mathrm{AM}$ & $m h / m h$ & $m h /+$ & $+/+$ & $\mathrm{AM}$ \\
\hline trans-18:1 & $0.76^{* * * *}$ & $0.95^{* * *}$ & $0.81 * * *$ & $0.71 * * *$ & $0.88^{* * * *}$ & $0.60^{* * *}$ & $0.88^{* * *}$ & $0.71^{* * *}$ & $0.92 * * *$ & $0.62 * * *$ & $0.97 * * *$ & $0.92 * * *$ \\
\hline cis 9, trans $11-18: 2^{\mathrm{z}}$ & $0.54 * *$ & $0.80 * * *$ & $0.58 * * *$ & $0.29 \mathrm{~ns}$ & $0.43^{*}$ & $0.65^{* * *}$ & $0.66^{* * *}$ & $-0.15 \mathrm{~ns}$ & $0.90^{* * *}$ & $0.73^{* * *}$ & $0.83 * * *$ & $0.56^{* * *}$ \\
\hline $18: 2 n-6$ & $0.61 * * *$ & $0.19 \mathrm{NS}$ & $0.45^{*}$ & $0.43^{*}$ & $0.54^{* *}$ & $0.21 \mathrm{NS}$ & $0.45^{*}$ & $0.46^{*}$ & $0.96^{* * *}$ & $0.51 * *$ & $0.89 * * *$ & $0.95^{* * *}$ \\
\hline$n-6$ & $0.59 * * *$ & $0.15 \mathrm{NS}$ & $0.40^{*}$ & $0.36 \mathrm{NS}$ & $0.50 * *$ & $0.21 \mathrm{NS}$ & $0.40^{*}$ & $0.40 \mathrm{NS}$ & $0.96 * * *$ & $0.51 * *$ & $0.89 * * *$ & $0.95^{* * *}$ \\
\hline $18: 3 n-3$ & $-0.39 \mathrm{NS}$ & $-0.12 \mathrm{NS}$ & $0.52 * *$ & $0.53^{* *}$ & $-0.40 \mathrm{NS}$ & $-0.20 \mathrm{NS}$ & $0.63^{* * *}$ & $0.39 \mathrm{NS}$ & $0.91 * * *$ & $0.43^{*}$ & $0.82 * * *$ & $0.70^{* * *}$ \\
\hline$n-3$ & $-0.14 \mathrm{NS}$ & $-0.21 \mathrm{NS}$ & $0.32 \mathrm{NS}$ & $-0.03 \mathrm{NS}$ & $-0.20 \mathrm{NS}$ & $-0.13 \mathrm{NS}$ & $0.35 \mathrm{NS}$ & $-0.04 \mathrm{NS}$ & $0.90 * * *$ & $0.43^{*}$ & $0.83 * * *$ & $0.70^{* * *}$ \\
\hline
\end{tabular}

${ }^{\mathrm{z}}$ Coeluted with trans7, cis9-18:2.

*, **, ***P<0.05, $P<0.01$, and $P<0.001$, respectively; NS, $P>0.05$. 
subcutaneous or intermuscular fat for any of the genotypes. This is likely due to the fact that the $18: 3 \mathrm{n}$ 3 elongation and desaturation products are synthesized when membrane bound and, therefore, are preferentially synthesized in lean muscle as opposed to adipose tissue (De Smet et al. 2004). For this reason, the phospholipid fraction of the adipose tissue or a phospholipid rich tissue (i.e., red blood cells) might be a more appropriate indicator of lean muscle concentrations of total n-3 fatty acids.

Overall, predicting intramuscular fatty acid composition using easily accessible depots is possible for some fatty acids exhibiting high between-tissue correlations (e.g., trans-18:1), but breed- and tissue-specific deposition may limit this for others. Further research using a larger number of animals and phenotypic correlations of fatty acids between various beef tissues will provide further insight into the lipid metabolism and the mechanisms of fatty acid deposition in different tissues and assist in genetic/genomic research where estimates of fatty acid profiles of the rib muscle from a large number of animals are required in order to facilitate the identification of genetic factors influencing fatty acid composition in beef. The identification of genes or gene markers that influence the fatty acid composition of beef could then enable the industry to further enhance the content of beneficial fatty acids or diminish contents of detrimental fatty acids in beef through genetic improvement.

N. Aldai gratefully acknowledges the support of a Marie Curie International Outgoing Fellowship within the 7th European Community Program.

Aldai, N., Najera, A. I., Dugan, M. E. R., Celaya, R. and Osoro, K. 2007. Characterisation of intramuscular, intermuscular and subcutaneous tissues in yearling bulls of different genetic groups. Meat Sci. 76: 682-691.

Aldai, N., Osoro, K., Barron, L. J. R. and Najera, A. I. 2006. Gas-liquid chromatographic method for analysing complex mixtures of fatty acids including conjugated linoleic acids (cis 9 trans 11 and trans 10 cis 12 isomers) and long-chain (n-3 or $\mathrm{n}-6)$ polyunsaturated fatty acids. J. Chromatogr. A 1110: 133139
Basarab, J. A., Mir, P. S., Aalhus, J. L., Shah, M. A., Baron, V. S., Okine, E. K. and Robertson, W. M. 2007. Effect of sunflower seed supplementation on the fatty acid composition of muscle and adipose tissue of pasture-fed and feedlot finished beef. Can. J. Anim. Sci. 87: 71-86.

Belury, M. A. 2002. Dietary conjugated linoleic acid in health: Physiological effects and mechanisms of action. Annu. Rev. Nutr. 22: 505-531.

Choi, N. J., Enser, M., Wood, J. D. and Scollan, N. D. 2000. Effect of breed on the deposition in beef muscle and adipose tissue of dietary n-3 polyunsaturated fatty acids. Anim. Sci. 71: 509-519.

De Smet, S., Raes, K. and Demeyer, D. 2004. Meat fatty acid composition as affected by fatness and genetic factors: a review. Anim. Res. 53: 81-98.

Grobet, L., Poncelet, D., Royo, J. L., Brouwers, B., Pirottin, D., Michaux, Ch., Menissier, F., Zanotti, M., Dunner, S. and Georges, M. 1998. Molecular definition of an allelic series of mutations disrupting the myostatin function and causing double-muscling in cattle. Mamm. Genome 9: 210-213.

Health Canada. 2006. Food and Nutrition. TRANSforming the food supply. Report of the Trans Fat Task Force Submitted to the Minister of Health. [Online] Available: http://www.hc-sc.gc.ca/fn-an/alt_formats/hpfb-dgpsa/pdf/nutr ition/tf-gt_rep-rap-eng.pdf [2008 Oct. 29].

Kramer, J. K. G., Cruz-Hernandez, C., Deng, Z., Zhou, J., Jahreis, G. and Dugan, M. E. R. 2004. Analysis of conjugated linoleic acid and trans 18:1 isomers in synthetic and animal products. Am. J. Clin. Nutr. 79 (Suppl. 6): 1137S-1145S.

Official Journal of the European Communities. 1999. European convention for the protection of vertebrate animals used for experimental and other scientific purposes. O. J. E. C. 24.8.1999: 222-229.

Real Decreto 147/1993. Condiciones sanitarias de produccion y comercializacion de carnes frescas. Boletin Oficial del Estado, 12 de marzo de 1993.

SAS Institute, Inc. 2001. SAS user's guide: Statistics. SAS for Windows, Version 8.2. SAS Institute, Inc., Cary, NC.

Scollan, N., Hocquette, J. F., Nuerberg, K., Dannenberger, D., Richardson and Moloney, A. 2006. Innovations in beef production systems that enhance the nutritional and health value of beef lipids and their relationship with meat quality. Meat Sci. 74: 17-33.

Ulbricht, T. L. V. and Southgate, D. A. T. 1991. Coronary heart disease: seven dietary factors. The Lancet 8773: 985-992. Webb, E. C. and O'Neill, H. A. 2008. The animal fat paradox and meat quality. Meat Sci. 80: 28-36. 